\title{
Concentrations of particulate matter in the North Frisian Wadden Sea
}

\author{
G.-A. PAffenhöfer* \\ Biologische Anstalt Helgoland (Litoralstation); \\ D-2282 List/Sylt, Federal Republic of Germany
}

\begin{abstract}
The amount of particulate matter for different size classes was determined in the North Frisian Wadden Sea over a period of 10 months from November 1973 to August 1974. Particle volume, particulate organic carbon and phaeopigment concentrations decrease with advancing season, reaching minima in June. It is concluded that concentrations of particulate matter including chlorophyll $\alpha$ were sufficiently high throughout the study period to support the growth and reproduction of appendicularia which abundantly occur in the Wadden Sea.
\end{abstract}

\section{INTRODUCTION}

The amount and nature of particulate matter in the range of approximately 1 to $100 \mu \mathrm{m}$ diameter largely determines the development and occurrence of herbivores and omnivores in the zooplankton community. Though particulate matter present has been measured in various ways (organic carbon, nitrogen, organic dry weight, chlorophyll $a$, particle volume, inverted microscope), the matter available has been most frequently expressed as a single parameter, for example carbon. This leaves open the important question of the relative proportions of living to non-living material. One recent effort dealt with the chemical, biological and volumetric determination of particulate matter from 2 to $150 \mu \mathrm{m}$ diameter (Zeitzschel, 1970), but it was not known how much organic matter in the various size classes was present. Separation into size classes is necessary to determine the potential amount of food available to juvenile and adult copepods, but this information alone indicates only the volume, not the nature, of matter available (Mullin, 1965; Poulet, 1974, 1976).

Combining the measurement of several parameters expressing amount, size and nature of particulate matter is required to assess food value and availability to different groups of abundant zooplankton. The objective of this investigation was to study seasonal changes and relationships between different "food" parameters in the North Frisian Wadden Sea. Most of the particulate matter in the Dutch Wadden Sea (about $75 \%$ ) is thought to originate in the North Sea (De Jonge \& Postma, 1974) where

\footnotetext{
* Present address: Skidaway Institute of Oceanography, P.O. Box 13687, Savannah, Georgia,
} USA. 
strong tidal currents keep much of the detritus suspended. The phytoplankton in the area of our collections consist regularly of pelagic and benthic species (cf. Drebes \& Elbrächter, 1976) which indicates considerable turbulence.

\section{MATERIAL AND METHODS}

The part of the Wadden Sea north of Sylt covers an area of $410 \mathrm{~km}^{2}$ at mean high and $240 \mathrm{~km}^{2}$ at mean low tide. The only connection with the open North Sea is the Lister Dyb between the North Sea islands of Sylt and Rømø, a channel with a minimum width of about $3 \mathrm{~km}$. The temperature minimum and maximum 1973/74 were 1.3 and $19.5^{\circ} \mathrm{C}$. Salinity generally ranged from 28 to $32 \%$.

My investigations commenced in October 1973 and ended in August 1974. Samples were collected 2 days each week. The study location was about $500 \mathrm{~m}$ east of List Harbour (Island of Sylt, Federal Republic of Germany) where samples were collected by bucket just before or after high tide. The water column was always well mixed due to strong tidal currents (up to 5 knots). The seawater was analyzed immediately upon arrival at the laboratory.

Chlorophyll $a$, phaeopigments, particulate organic carbon and particulate nitrogen were determined on unfiltered material and on that passing through meshes of 30 and $180 \mu \mathrm{m}$. The seawater was gently filtered through each mesh. This screening procedure implies that all irregularly shaped particles smaller than $50 \%$, and all subspherical particles smaller than $80 \%$ of the mesh size are not retained (Sheldon $\&$ Parsons, 1967a). In addition, breakage of unknown percentages of long chains mainly of the genera Asterionella, Chatoceros, and Thalassiosira could not be avoided. The $30 \mu \mathrm{m}$ mesh was selected to measure the particulate matter available to appendicularians as the filtering mechanism of Oikopleura dioica has a width of 30 to $40 \mu \mathrm{m}$. The particulate matter passing through a mesh of $180 \mu \mathrm{m}$ should include almost all the material which can be ingested by copepods.

Chlorophyll $a$ and phaeopigments were determined with a Turner fluorometer III using a high sensitivity door and a F4T.5. lamp, the method of Strickland \& Parsons (1968). Particulate organic carbon (POC) and particulate nitrogen (PN) were determined using a Hewlett-Packard Model 185 CHN-Analyzer. Seawater samples from 25 to $200 \mathrm{ml}$ were filtered at a vacuum of $150 \mathrm{~mm} \mathrm{Hg}$ on precombusted Whatman GFC filters, rinsed twice with $2.5 \mathrm{ml}$ distilled water, dried for 48 to $72 \mathrm{~h}$ at $60^{\circ} \mathrm{C}$ and stored in a desiccator until combustion. As distilled water rinses may cause a loss of organic matter, one test was carried out to compare samples with and without rinsing water (Table 1). The results indicated considerable losses in the $250 \mathrm{ml}$ samples $(24 \%$ $\mathrm{C}$ and $29 \% \mathrm{~N}$ lost). Most of the samples taken ranged from 25 to $150 \mathrm{ml}$. It should be noted that the retention by GFC-filters is not as high as that of the collection apparatus of O. dioica $(0.1 \times 0.8 \mu \mathrm{m}$ mesh; Jørgensen, 1966).

The particle volume of material passing through $30 \mu \mathrm{m}$ mesh was determined using a Coulter Counter $\mathrm{ZB}$ with an orifice of $100 \mu \mathrm{m}$ diameter. Material passing through $180 \mu \mathrm{m}$ mesh was analyzed with a 100 and $400 \mu \mathrm{m}$ diameter orifice. Sample volume for the $100 \mu \mathrm{m}$ orifice was $0.55 \mathrm{ml}$, for the $400 \mu \mathrm{m}$ orifice $23.32 \mathrm{ml}$ using a 
Table 1

Organic carbon (C) and nitrogen (N) content of one seawater sample washed through $30 \mathrm{~cm}$ mesh with and without being rinsed with distilled water $(\mu \mathrm{g} / \mathrm{l})$ on July 9,1974

\begin{tabular}{|ccccc|}
\hline Seawater & \multicolumn{2}{c}{ No dist. water } & \multicolumn{2}{c|}{ Rinsed with $2 \times 2.5 \mathrm{ml}$ dist. water } \\
sample size & $\mathrm{C}$ & $\mathrm{N}$ & $\mathrm{C}$ & $\mathrm{N}$ \\
\hline $25 \mathrm{ml}$ & 532 & 104 & 532 & 104 \\
$100 \mathrm{ml}$ & 548 & 77 & 531 & 70 \\
$250 \mathrm{ml}$ & 603 & 90 & 458 & 64 \\
\hline
\end{tabular}

Coulter Timer. The procedure allowed us to reliably measure particle diameters from 2 to $25 \mu \mathrm{m}$ passing through $30 \mu \mathrm{m}$ mesh and 2 to $63 \mu \mathrm{m}$ passing through $180 \mu \mathrm{m}$ mesh. The number of particles above $63 \mu \mathrm{m}$ was too low for satisfactory statistical evaluation. To keep coincidence low the samples were often diluted to 2.5 to $20 \%$ of their original volume using seawater filtered immediately before use through $0.45 \mu \mathrm{m}$ millipore filters. The samples were counted at 22 different settings (Aperture Current, Amplification) with both orifices overlapping for certain particle sizes. This resulted in 15 different settings ( 7 with the 100,8 with the $400 \mu \mathrm{m}$ aperture) used for the calculation of the particle volume for sizes from 2 to $63 \mu \mathrm{m}$ diameter.

The volume settings of 0.5 and $2.0 \mathrm{ml}$ on the Coulter Counter $\mathrm{ZB}$ were calibrated several times. It was found that $0.55 \mathrm{ml}$ and $2.24 \mathrm{ml}$, respectively, passed through an orifice at the above mentioned settings indicating that the original Coulter calibrations were not correct.

The volume of particulate matter from 2 to $63 \mu \mathrm{m}$ diameter was computed using the data up to $10 \mu \mathrm{m}$ diameter from the $100 \mu \mathrm{m}$ orifice and those above $10 \mu \mathrm{m}$ from the $400 \mu \mathrm{m}$ orifice. Particle concentration in relation to size is presented according to Sheldon et al. (1972).

\section{RESULTS}

Most of the results are presented as monthly averages (Fig. 1). Each data point is the mean of 6 to 10 determinations, except that from August when only two measurements were made. The particle volume data indicate highest values during winter. The highest monthly average for the range 2 to $25 \mu \mathrm{m}$ diameter was 19.48 ppm in December compared with the lowest average in June 1974 at 1.93 ppm. A comparison of monthly data for the small and large ranges shows significant correlations for all months except April (Table 2). A developing phytoplankton bloom changed the relation of both particle ranges during that month. Correlations (1) and (4) are of limited importance as the parameters in each correlation are not stochastically independent.

Particulate organic carbon (POC) values decreased in a manner similar to particle volume (Fig. 1), attaining minimum values during June. The fraction passing through $180 \mu \mathrm{m}$ mesh was close to $90 \%$ of the total from December through May, indicating that most of the POC was near or smaller than $100 \mu \mathrm{m}$ in diameter (Table 3). During summer the POC passing $180 \mu \mathrm{m}$ mesh dropped to $60 \%$ of the total. From December 


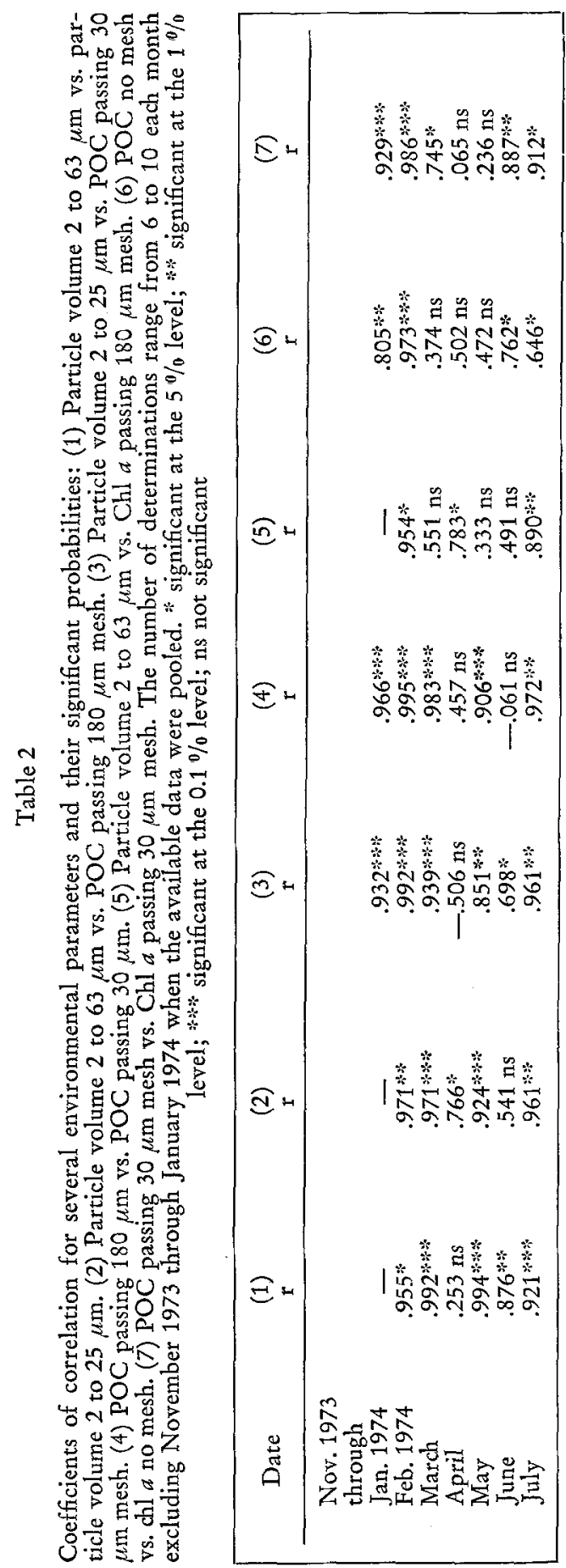




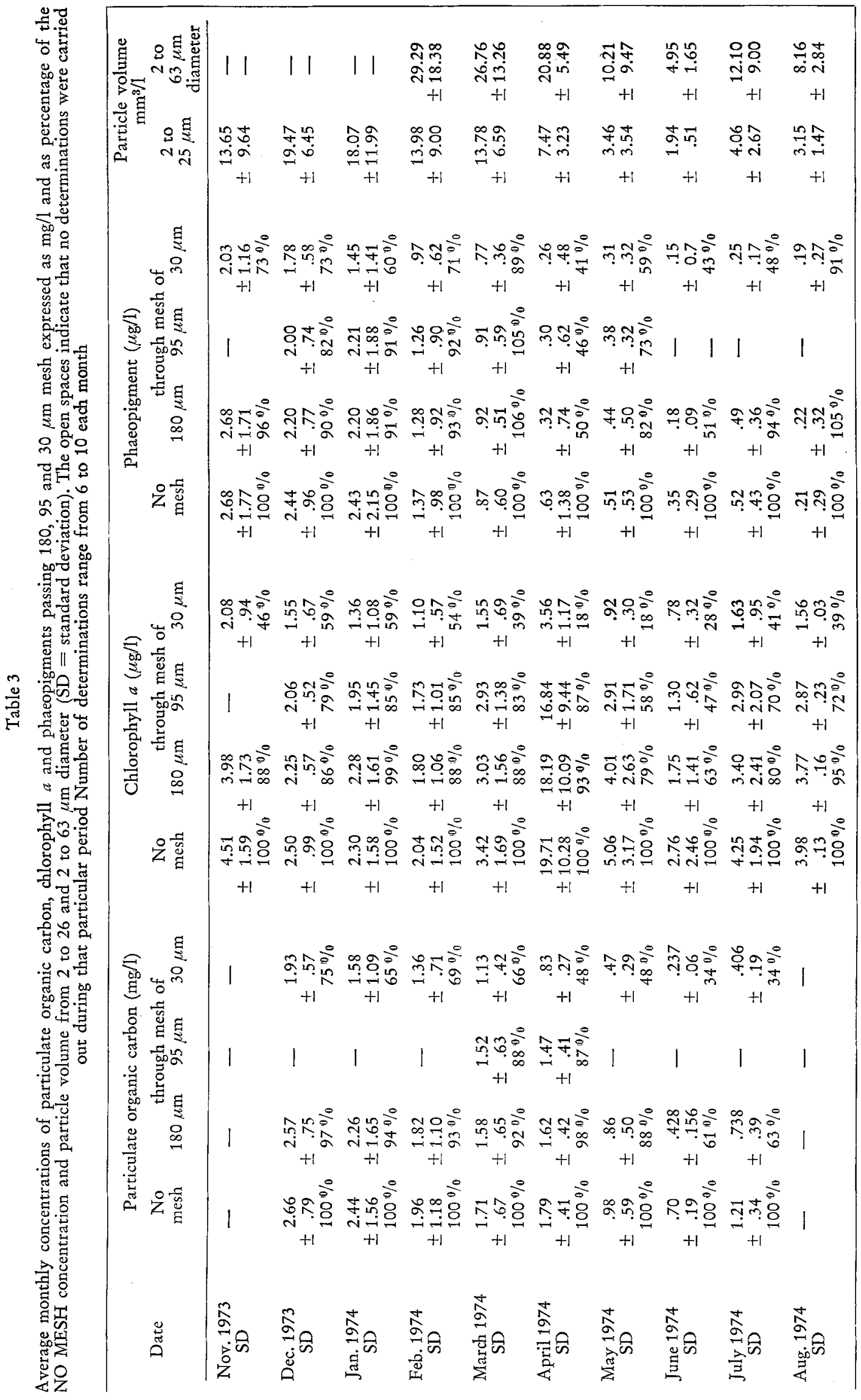


to March the majority of POC was in the fraction passing $30 \mu \mathrm{m}$ mesh, decreasing evenly until June when it made up only one third of the total. Particle volume (2 to $63 \mu \mathrm{m} \phi$ ) correlated significantly with POC passing the $180 \mu \mathrm{m}$ mesh except in June when both parameters reached minima. Plots of POC passing through $180 \mu \mathrm{m}$ mesh against that passing through $30 \mu \mathrm{m}$ mesh were not significant in April and June.
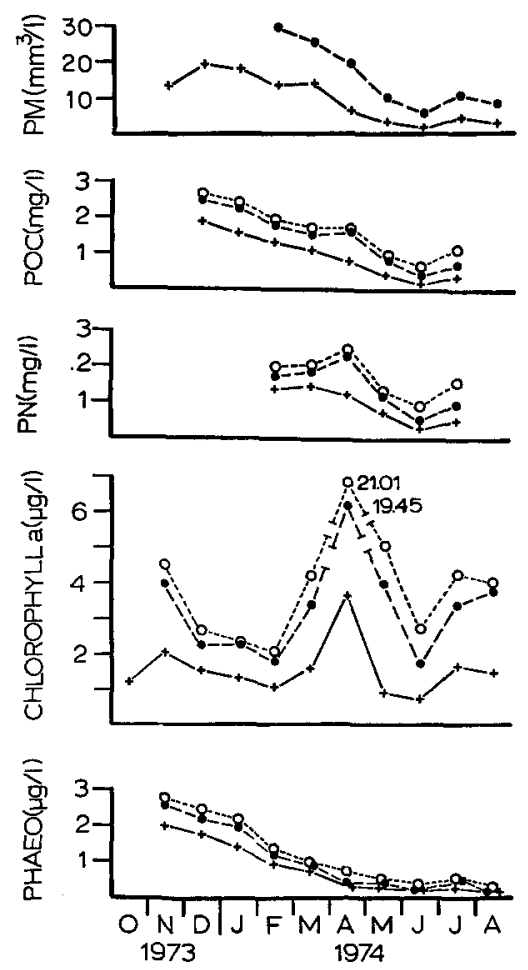

Fig. 1: Monthly averages of particulate matter (PM) measured in $\mathrm{mm}^{3}$ of particulate matter per liter of seawater, particulate organic carbon (POC), particulate nitrogen (PN), chlorophyll $a$ and phaeopigments (Phaeo.). Symbols: $+=$ particulate matter passing through $30 \mu$ mesh; $\mathrm{o}=$ passing through $180 \mu$ mesh; o = no mesh used

A spring phytoplankton bloom began toward the end of March and ceased in mid-May. Most of the bloom species occurred as chains which did not pass through the $30 \mu \mathrm{m}$ mesh. The high amounts of chlorophyll $a$ in unfiltered water and that passing through $180 \mu \mathrm{m}$ mesh in April coincided with increases in PN but did not alter the POC values which were similar to those from March. The majority of the POC in April as in earlier months was non-living. POC (unfiltered) did not correlate with chlorophyll a during the months of high chlorophyll. POC (passing $30 \mu \mathrm{m}$ mesh) correlated significantly with chlorophyll $a$ of the same size group except in April and May. It appeared that the phytoplankton carbon was a rather even fraction of the total POC during each month of relatively low phytoplankton concentration. 


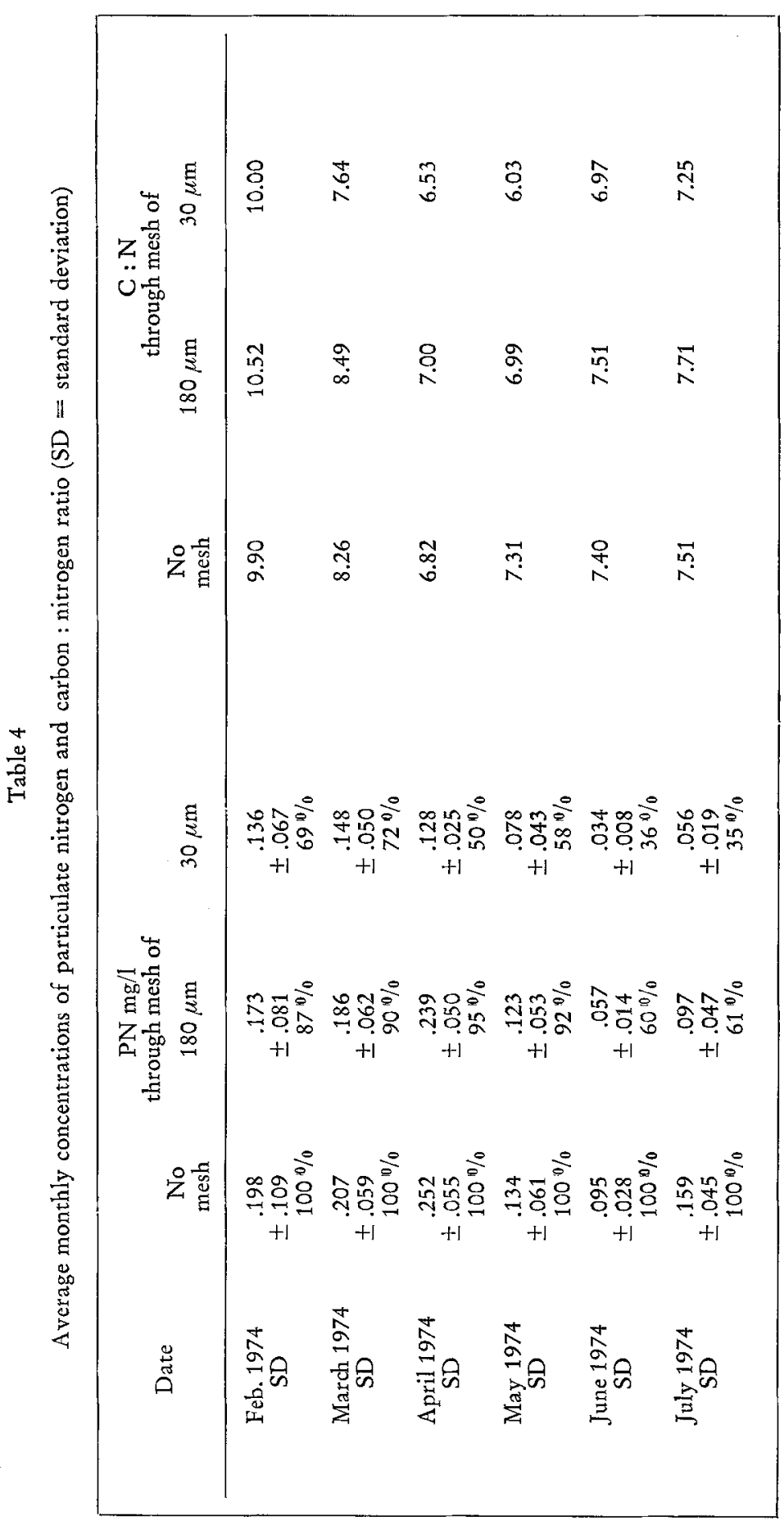


Data available for particle volume from each month are plotted against $P O C$ in Figure 2, which shows considerable variation.

One $\mathrm{mm}^{3}$ of particulate matter (range 2 to $63 \mu \mathrm{m}$ diameter) contains $51 \mu \mathrm{g} \mathrm{C}$ in material passing through a $180 \mu \mathrm{m}$ mesh (see also Sheldon, 1974). During April (diatom bloom) the carbon to volume ratio was higher and during June lower than the average. The intercept at $0.302 \mathrm{mg} \mathrm{C}$ could be attributed to particulate matter smaller than 2 and larger than $63 \mu \mathrm{m}$ being sampled on the filters but not included in the volume determination (Zeitzschel, 1970).

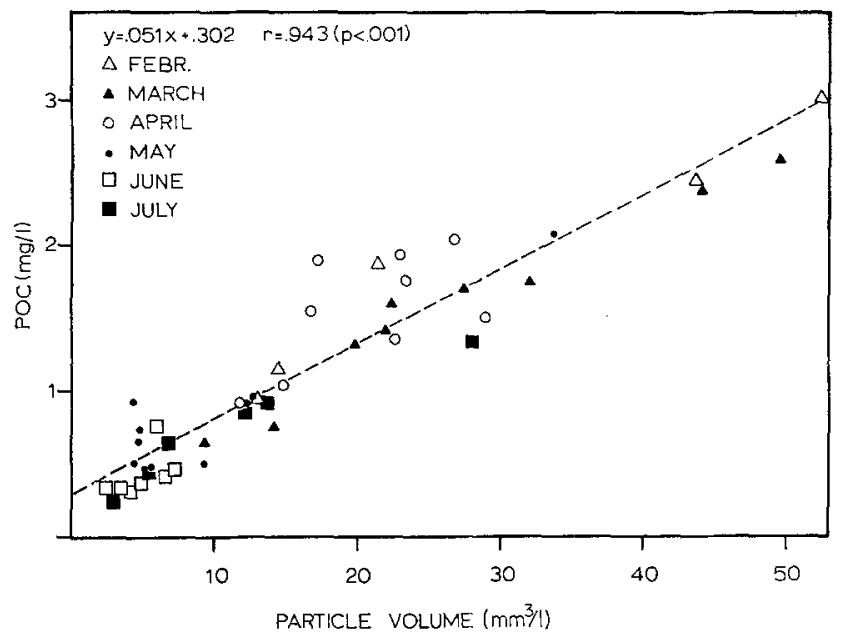

Fig. 2: Particle volume as determined with a Coulter Counter ZB (2 to $63 \mu \mathrm{m} \varnothing)$ vs. particulate organic carbon passing through $180 \mu \mathrm{m}$ mesh

Phaeopigments decreased evenly with proceeding season and did not change considerably after April. In several samples in late spring and summer the values were registered as zero when they amounted to less than $10 \%$ of chlorophyll $a$ and phaeopigments combined.

Particulate nitrogen (PN) concentrations correlated with POC when monthly average values (data obtained from passing through 180 and $30 \mu \mathrm{m}$ mesh) were compared as a percentage of that in unfiltered material (Tables 3 and 4). The $C: N$ ratio of each size range decreased from February to April and showed little change in the following months. This indicated that the percentage of living matter increased from February to April, assuming even values thereafter.

During June and July the amount of POC and PN passing through the $30 \mu \mathrm{m}$ mesh dropped from 75 to $34 \%$ of the total; that passing through $180 \mu \mathrm{m}$ mesh decreased sharply from 95 to about $61 \%$, signifying a considerable increase in the amount of larger $(>180 \mu \mathrm{m})$ and decrease of smaller particulate matter (Table 3).

Particle size spectra were derived from the counts of a total of 22 different settings of the Coulter Counter with the 100 and $400 \mu \mathrm{m}$ orifices overlapping. Spectra 
characteristic of certain parts of a month and which showed the spectral changes occurring during various periods are presented. Four spectra are plotted together for better comparison (Fig. 3).

From February 27 to March 21 the volume in almost all of the 15 size ranges dropped with volume peaks in the range from 10 to $14 \mu \mathrm{m}$. With the onset of the spring bloom (end of March) the spectrum peaks shifted toward larger volumes


Fig. 3: Particle spectra from the North Frisian Wadden Sea determined with $100 \mu \mathrm{m}$ and $400 \mu \mathrm{m}$ diameter orifices of a Coulter Counter

(28 $\mu \mathrm{m}$ diameter). There the peak remained until May 20 , coinciding with the phytoplankton bloom. Highest particle volumes were reached on April 16 to 18; also, on those days the highest chlorophyll a concentrations were measured, and from then on the volumes decreased gradually until May 20. From May to August maxima were in the range from 9 to $28 \mu \mathrm{m}$ diameter. The amount of particulate matter from 2 to $6 \mu \mathrm{m}$ diameter decreased with the advancing season and changed little after mid-April.

Varying wind velocities affected the total amount of particulate matter in the water column. Strong winds led to an increase of suspended benthic material. Except in March $(\gamma=.781, \mathrm{P}<.01)$ no significant correlation could be found between wind speed and particle volume. 


\section{DISCUSSION}

A variety of studies have been carried out on the amount, size and size distribution of particulate suspended matter in the sea. For instance, in the Gulf of California Zeitzschel (1970) found significant correlations between particle volume $(2-150 \mu \mathrm{m}$ diameter), seston, phytoplankton carbon, POC, PN and chlorophyll a. One $\mathrm{mm}^{3}$ of particles contained $220 \mu \mathrm{g} \mathrm{C}$, one $\mathrm{mm}^{3}$ of phytoplankton $42 \mu \mathrm{g} \mathrm{C}$. One $\mathrm{mm}^{3}$ of particulate matter in the study area of the Wadden Sea had an average of $51 \mu \mathrm{g} \mathrm{C}$. During April the $\mu \mathrm{g} \mathrm{C} \cdot \mathrm{mm}^{-3}$ increased to 64 when the phytoplankton were characterized by blooms of Asterionella glacialis, A. kariana and Skeletonema costatum (G. Drebes, personal comm.). For comparative purposes one $\mathrm{mm}^{3}$ of $S$. costatum has an average carbon content of 115 to $200 \mu \mathrm{g}$. During phytoplankton blooms in the Straits of Georgia (Canada) the suspended matter contained $52 \mu \mathrm{g} \mathrm{C} \cdot \mathrm{mm}^{-3}$ (Parsons et a1., 1967; Sheldon \& Parsons, 1967b). Significant correlations were found between particle volume, nanoplankton carbon, microplankton carbon and chlorophyll (Parsons, 1969). Most of these data must be interpreted with caution as the Coulter Counter does not measure all particles accurately (Ilmavirta, 1974 Leslie et al., 1975). The significant relationship between particle volume and POC is attributed to non-living matter being far more abundant than living matter in all samples, resulting in low variability.

Seasonal variations in particle volume (1.6 to $144 \mu \mathrm{m}$ particle diameter) were observed in Bedford Basin, Nova Scotia (Poulet, 1974). Minima were found between December and February (near $1 \mathrm{ppm}$ ) maxima in March (18 to $40 \mathrm{ppm}$ ). The volume of particulate matter in the size range of 3 to $120 \mu \mathrm{m}$ diameter was determined during four cruises from March to November in the southern North Sea (Gieskes, 1972). Near-shore concentrations ranged from 3.8 to $5.8 \mathrm{ppm}$ (early March) to a maximum of 9.0 to $19.6 \mathrm{ppm}$ (early September) falling again to 3.2 to $5.1 \mathrm{ppm}$ in early November. In the North Frisian Wadden Sea near Sylt, concentrations of particulate matter ( 2 to $63 \mu \mathrm{m}$ diameter) decreased from $29.3 \mathrm{ppm}$ (February) to $5.67 \mathrm{ppm}$ (June). The decrease in POC and particle volume in the different size ranges from winter to early summer could be attributed to changes in meteorological conditions and to increases in benthic and planktonic feeding with increases in temperature and in grazer density, which will be discussed later.

Phaeopigment concentrations above $1 \mu \mathrm{g} \cdot 1^{-1}$ were repeatedly observed in Narragansett Bay from May to November (Durbin et al., 1975). From December through April concentrations were below 0.8 with one exception. Concentrations in the North Frisian Wadden Sea decreased from 2.8 to about $0.5 \mu \mathrm{g} \cdot 1^{-1}$ between November to April remaining even through summer. The high amounts of phaeopigments from November to April are considered to be caused by degrading processes and continued transport of particulate matter from the open North Sea into the Wadden Sea (De Jonge \& Postma, 1974).

The relative amount of organic matter and chlorophyil (percentage of the total) in previous reports was highest for particles smaller than $30 \mu \mathrm{m}$. Particles from 1 to $33 \mu \mathrm{m}$ accounted for $77 \%$ of the organic carbon of particulate matter ranging from 1 to $500 \mu \mathrm{m}$ diameter (Mullin, 1965). Particles smaller than $8 \mu \mathrm{m}$ accounted for $60 \%$ 
of total living carbon in two eastern Canadian Bays throughout one year (Sutcliffe, 1972). Chlorophyll a passing through $35 \mu \mathrm{m}$ mesh accounted for 61.5 to $100 \%$ of the chlorophyll a passing through $163 \mu \mathrm{m}$ mesh in Chesapeake Bay (McCarthy et al., 1974). In the North Frisian Wadden Sea the relationships differ as the amount of chlorophyll a passing through $30 \mu \mathrm{m}$ mesh decreased from $59.2 \%$ of the total in December to $17.6 \%$ in April. The low percentages coincide with a bloom of chain-forming diatoms which do not usually pass through $30 \mu \mathrm{m}$ mesh. POC passing through $30 \mu \mathrm{m}$ mesh followed a different pattern, decreasing from $74.5 \%$ of the total in December to near $34 \%$ in June and July. The relatively large amounts of POC and PN not passing through $180 \mu \mathrm{m}$ mesh during June and July (near $40 \%$ of the total) could be partly attributed to large colonies of Phaeocystis pouchetii (Künne, 1952, and personal observations).

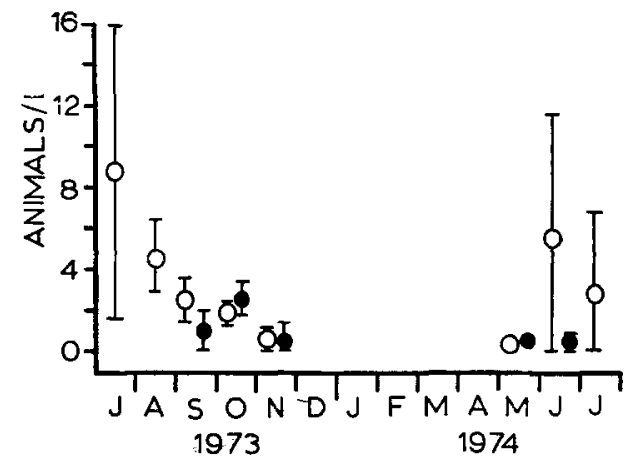

Fig. 4: Average monthly concentrations of Oikopleura dioica (o) and Fritillaria boreclis (•) in the North Frisian Wadden Sea. The $95 \%$ confidence limits are presented for all months except May 1974 when samples were taken on only 2 occasions. (Modified after Paffenhöfer, 1976)

Particle spectra from 3 to $120 \mu \mathrm{m}$ size from the southern North Sea near the Netherland coast (stations 3 and 7) were characterized by 2 or more peaks from March through summer (Gieskes, 1972; Eisma \& Gieskes, 1977). Non-living matter, as found off Sylt from November through March, dominated the March and November samples. In April flagellatc blooms developed followed by diatom blooms in late summer. Particle spectra from Bedford Basin (Nova Scotia, Canada) varied considerably from January to November (Poulet, 1974) ranging from high concentrations near $2 \mu \mathrm{m}$ diameter to others between 30 and $60 \mu \mathrm{m}$. Particle spectra from the North Frisian Wadden Sea were rather uniform being characterized by singular, mostly broad peaks often indicating high particle concentrations ( $>0.3 \mathrm{ppm}$ ) in each of the ten size classes from 6 to $60 \mu \mathrm{m}$ diamter, thereby implying that the majority of the particulate matter over most of the year is available to calanoid copepods such as the abundant Pseudocalanus elongatus and Temora longicornis.

The only zooplankton group which has been quantified reliably for a longer period of time are the appendicularia (Paffenhöfer, 1976). Appendicularia have at times been found in abundance in the Wadden Sea (Künne, 1952) and are considered 
to be the major food of the larvae of plaice and sand-eel in the Southern Bight (Ryland, 1964). They consume particulate matter in the range from approximately 0.1 to $30 \mu \mathrm{m}$ diameter (Jørgensen, 1966; Paffenhöfer, 1976).

Bucket samples collected over a period of 13 months (Paffenhöfer, 1976) show that appendicularian densities were highest when POC and particle concentrations were lowest (Figs. 1 and 4), indicating that food was not limiting. The particulate matter passing through $30 \mu \mathrm{m}$ mesh was thought to be available as food. The occurrence of both species of appendicularians seemed to be regulated by temperature (Paffenhöfer, 1976). No "crashes" of appendicularian populations as reported by Seki (1973) were observed. The continuous occurrence of a population of $O$. dioica during the warmer months is attributed not only to an adequate food supply but also to continuous losses of appendicularians (by mortality) thus avoiding bloom conditions which might fatally deplete the food resource. Data on the body length of $O$. dioica showed that the average size changed little during 48 to 72 hours (range of $\mathrm{x}=331$ to $488 \mu \mathrm{m}$ ). This points towards continous removal of $O$. dioica as their generation time at $16^{\circ} \mathrm{C}$ is short ( 6 days). The high particle concentrations in Wadden Sea waters lead to the assumption that the majority of non-carnivorous zooplankton is not food-limited during the entire year.

Acknowledgements. The author expresses thanks to Dr. W. Hickel and the Deutsche Forschungsgemeinschaft for financial support (Grants $\mathrm{Pa}$ 124/6, Hi 225/1), Mrs. Reiners for sample analysis and especially Ms. P. Hayes who conducted most of the particle size analysis. Drs. D. W. Menzel and W. W. C. Gieskes improved the manuscript with their constructive criticism which is gratefully acknowledged.

\section{LITERATURE CITED}

Drebes, G. \& Elbrächter, M., 1976. A checklist of planktonic diatoms and dinoflagellates from Helgoland and List (Sylt), German Bight. Botanica mar. 19, 75-83.

Durbin, E. G., Krawiec, R. W. \& Smayda, T. J., 1975. Seasonal studies on the relative importance of different size fractions in Narragansett By (USA). Mar. Biol. 32, 271-287.

Eisma, D. \& Gieskes, W. W. C., 1977. Particle size spectra of nonliving suspended matter in the southern North Sea. Ned. Inst. Onderzoek Zee, Texel, 22 pp.

Gieskes, W. W. C., 1972. Primary production, nutrients, and size spectra of suspended particles in the Southern North Sea. Ned. Inst. Onderzoek Zee, 'Texel, 1972-16, 1-39 (mimeo).

Ilmavirta, V., 1974. Electronic particle counting applied in phytoplankton studies in three southern Finnish lakes. Ann. bot. fenn. 11, 105-111.

Jonge, V. N. de \& Postma, H., 1974. Phosphorus compounds in the Wadden Sea. Neth. J. Sea Res. 8, 139-153.

Jorgensen, C. B., 1966. Biology of suspension feeding. Pergamon Press, Oxford, 357 pp.

Künne, C., 1952. Untersuchungen über das Großplankton in der Deutschen Bucht und im Nordsylter Wattenmeer. Helgoländer wiss. Meeresunters. 4, 1-54.

Leslie, J., Devey, L., Munawar, M., Nauwerck, A. \& Pickett, E., 1975. A comparison of electronic particle counters and inverted microscope methods for counting phytoplankton. Tech. Rep. Great Lakes Biolimnol. Lab., Burlington, Ontario, Canada.

McCarthy, J. J., Taylor, W. R. \& Loftus, M. E., 1974. Significance of nanoplankton in the Chesapeake Bay estuary and problems associated with the measurement of nanoplankton productivity. Mar. Biol. 24, 7-16. 
Meuleman, E. A., 1972. Host-parasite interrelationships between the freshwater pulmonate Biomphalaria pfeifferi and the trematode Schistosoma mansoni. Neth. J. Zool. 22, 355-427.

Mullin, M. M., 1965. Size fractionation of particulate organic carbon in the surface waters of the Western Indian Ocean. Limnol. Oceanogr. 10, 453-462.

Paffenhöfer, G.-A., 1976. On the biology of appendicularia of the southeastern North Sea. In: Proceedings of the 10th European Symposium on marine biology. Ed. by G. Persoone \& E. Jaspers. Universa Press, Wetteren, 2, 437-455.

Parsons, T. R., 1969. The use of particle size spectra in determining the structure of a plankton community. J. oceanogr. Soc. Japan 25, 172-181.

- LeBrasseur, R. J. \& Fulton, J. D., 1967. Some observations on the dependence of zooplankton grazing on the cell size and concentration of phytoplankton blooms. J. oceanogr. Soc. Japan 23, 10-17.

Poulet, S. A., 1974. Seasonal grazing of Pseudocalanus minutus on particles. Mar. Biol. 25, 109-123.

- 1976. Feeding of Pseudocalanus minutus on living and nonliving particles. Mar. Biol. 34, $117-125$.

Ryland, J. S., 1964. The feeding of plaice and sand-eel larvae in the southern North Sea. J. mar. biol. Ass. U. K. 44, 343-364.

Sheldon, R. W. \& Parsons, T. R., 1967a. A practical manual on the use of the Coulter Counter in Marine Science. Coulter Electronics Sales Co., Toronto, 65 pp.

- 1967b. A continuous size spectrum for particulate matter in the sea. J. Fish. Res. Bd Can. 24, 909-915.

- Prakash, A. \& Sutcliffe, W. H., 1972. The size distribution of particles in the ocean. Limnol. Oceanogr. 17, 327-340.

Seki, H., 1973. Red tide of Oikopleura in Saanich Inlet. Mer (Bull. Soc. franco-jap. oceanogr.) $11,153-158$.

Strickland, J. P. H. \& Parsons, T. R., 1968. A practical handbook of seawater analysis. Bull. Fish. Res. Bd Can. 167, 1-311.

Sutcliffe, W. H., jr., 1972. Some relations of land drainage, nutrients, particulate material, and fish catch in two eastern Canadian bays. J. Fish. Res. Bd Can. 29, 352-362.

Zeitzschel, B., 1970. The quantity, composition and distribution of stispended particulate matter in the Gulf of California. Mar. Biol. 7, 305-318. 